\title{
An empirical study to investigate the effects of social capital on social contribution
}

\author{
Mohammad Reza Iravani ${ }^{\mathbf{a}^{*}}$ and Zeynab Razi ${ }^{\mathrm{b}}$
}

${ }^{a}$ Department of Social Work, Islamic Azad University, Khomeinishahr Branch, Daneshjou Blvd, Iran ${ }^{b}$ Department of Sociology, Islamic Azad University, Jahrom Branch, Iran

\begin{tabular}{l}
\hline A R T I C L E I N F O \\
\hline Article history: \\
Received April 5, 2011 \\
Received in Revised form \\
June, 3, 2011 \\
Accepted 5 June 2011 \\
Available online \\
6 June 2011 \\
\hline Keywords: \\
Social capital \\
Social contribution \\
Social solidarity \\
Social relation
\end{tabular}

\section{A B S T R A C T}

\begin{abstract}
This paper performs an empirical study to study the effects of social capital on social contribution for a group of people of 18-year-orl who lived in a city of Meymand/Iran. The survey selects 300 people out of 5026 people based on a two-stage cluster sampling and distributed questionnaire among them. The results are analyzed based on descriptive and inductive terms, which indicate a positive and meaningful relation between social capital and social solidarity. However, there is a negative and meaningful relationship between social opposition and conflict with organizations while there are some opposite relationships among networks of social relationships instead of level of internal group relationships.
\end{abstract}

(C) 2011 Growing Science Ltd. All rights reserved.

\section{Introduction}

One of the primary concerns on societies is to find a suitable method to measure the progress of a nation. One of the main indications of the progress of a nation is to look at growth domestic product (GDP). However, there have been many studies to argue that GDP itself cannot be a good measure of the progress of economy (Natoli \& Zuhair, 2010). There have been alternative indices versus GDP growth to measure the progress of a nation such as human development index (HDI) (UNDI, 1990) and genuine progress indicator (Cobb \& Cobb, 1994). The HDI is not a suitable method to capture the progress concept since most part of the information about the HDI is achieved by in per capita GDP. This relatively strong and positive correlation outcome creates motivation on making additional information to measure the progress of a nation (McGillivray \& White, 1993; Dijkstra \& Hanmer, 2000; Cahill, 2005). Despite this, HDI has been widely used as a major improvement over standard progress approaches. The measure goes beyond commodities and towards an interdisciplinary approach.

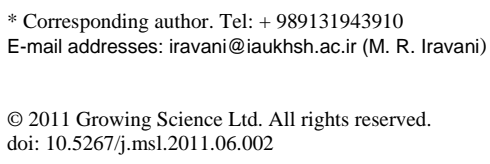


Nascimento and Marteleto (2008) studied the behavior of the information through the tools of informational practice in a social field and knowledge domain and reported that both the products and subjects of a domain of knowledge, inserted in social fields, are expressions of their informational practice. Park and Bae (2004) investigated recently introduced new venture strategies in a developing country and tried to identify a typology and examine the growth patterns through case studies. Orhan and Scott (2001) investigated to find a suitable answer on why women enter into entrepreneurship. Roomi et al. (2009) tried to understand the nature and activities of growth-oriented women-owned businesses in the East of England by highlighting the issues faced by women entrepreneurs during the growth process. The results of their survey indicated that most women do not opt to develop growthoriented businesses. Therefore, they prefer to choose small, non-scalable, locally focused businesses providing services or operating in low-tech industries. Werbel and DeMarie (2005) studied aligning strategic human resource management and person-environment fit. They explained that strategic human resource management helps create vertical linkages of human resource management (HRM) attributes with company strategy as well as horizontal linkages that integrate practices among HRM functions.

Contribution of people to social affairs is one of the most important arguments in social politics derived from social nature of human and other resources. In fact, social activities play important role on making decision and politic of general structures. According to William and White (1999) contribution increases the sense of responsibility and activity and decreases inordinate concentration desires and also fair distribution of tasks put the millstone of tasks on the shoulder of all makers' decision. One of the effective factors on social contribution is social capital, which is recently considered as the most basic factor by attracting scientific meetings interest. In Colman opinion, social capital is the part of social structure allowing actors to use for their profit. In his view, social capital includes knowing edges, understandings, norms, principles and expectations about interaction

that people lead to different activities (Reamer, 2006). The primary objective of social capital is empowering and activating people strength within institutions and networks of activities. Therefore, it makes the filed for individuals to take contribution sense and bed to hat potential contribution.

In this paper, we propose a new method to study the effects of social capital on social contribution. This paper is organized as follows. We first present the conceptual model as well as the necessary definitions required in section 2. Section 3 describes the details of our survey results and finally concluding remarks are given in section 4 to summarize the contribution of the paper.

\section{The proposed conceptual framework}

As we explained earlier, social contribution can be performed in different ways such as social solidarity, social network, social trust and social opposition. The social solidarity consists of three different groups of interior, exterior solidarity and its contribution to organizations. The social network includes two groups of interior and exterior network relationships. In social trust, we look for interior, exterior trusts as well as trust to state organizations. Finally, social oppositions are activities associated with interior and exterior group opposition as well as opposition within organizations.

\subsection{Research assumption}

The study of this paper considers the following assumptions.

- There is a positive and meaningful relation between social capital and social contribution.

- There is a positive and meaningful relation between social capital and the network of citizen relations.

- There is a positive and meaningful relation between social capital and belief to necessity of implementing contribution.

- There is a positive and meaningful relation between social capital and social solidarity.

- There is a positive and meaningful relation between social capital and social opposition. 
The proposed study of this paper uses questionnaire form to gather the necessary information associated with the survey. The survey is used for the people who lived in small city called Maymand, which is a little city located in $100 \mathrm{~km}$ south far from Shiraz, capital of Fars province, Iran. According to the official census held in 2006, there are 5026 people residing in this city including 2575 men and 2451 women. We have used the following formula to calculate the minimum number of sample size,

$n=\frac{N \times z_{\alpha / 2}^{2} \times p \times q}{\varepsilon^{2} \times(N-1)+z_{\alpha / 2}^{2} \times p \times q}$,

where $N$ is the population size, $p=1-q$ represents the yes/no categories, $z_{\alpha / 2}$ is CDF of normal distribution and finally $\varepsilon$ is the error term. Since we have $p=0.5, z_{\alpha / 2}=1.96$ and $N=5026$, the number of sample size is calculated as $n=300$.

For reliability and validity of the items, 40 questionnaires are distributed and after gathering by using Chronbach Alfa coefficient (Cronbach, 1951), the items have the coefficient lower that 0.7 omitted as unreliable items. The Chronback alpha for other items for social trust, network social relations, level of contribution and social solidarity are calculated as $0.71,0.93$ and 0.840 .94 , respectively. Next, we discuss the details of the results of our survey. As we explained earlier, we have studied four important aspects of social activities and we briefly explain each of them before we go through the details of our discussion. Note that the questions were organized based on Likert scale (1932).

\subsection{Social trust}

Trust is normally used for measuring the level of social capital and it is one concrete concept whose evaluation is difficult, because there is different definition for various people. Trust includes the tendency of individual for accepting risk in social situation which is based on the sense of confidence to the point that people act as expected and prefer the method of supporting.

\subsection{Social solidarity}

Solidarity means consensus among members of society that is consequent of accepting and internalizing normative / value system of society and existence of consensus and it is one of the aspects of cognitive social capital. It is also considered as an index in the level of community unity that shows group tendency to their members. In addition, Chaplin (1997) claims that requirements of solving two problems is predictability of social behaviors and social interaction and by eliminating those problems and introducing social counter trust, the field of inter contribution of social contribution will be pre constraint for correcting and social development and also requirements will be provided for local society.

\subsection{Social opposition}

Opposition means the battle, which occurs among different parts of society on valuable accessible resource. There are different social oppositions, which could occur among various people such as having discussion among people in a society, the competition between some cities or nations. Opposition means enmity, conflict, scrimmage and in turn concepts like unity, order and solidarity opposition is resulted from crashing, when two or more people or specific group together are challenging for some reason either mentally and physically.

Table 1 summarizes the definitions of all items, which are used for the proposed study of this paper. 


\section{Table 1}

Operational definition of present items in the research

\begin{tabular}{|c|c|}
\hline Items & Operational definition \\
\hline \multirow[t]{3}{*}{ Social trust } & All people are trusty \\
\hline & If you take a time other, they will abuse \\
\hline & Level of trust to family, friends, municipality \\
\hline \multirow[t]{3}{*}{ Social solidarity } & Social solidarity life of all persons is interrelated \\
\hline & If the problem occurs for others, all should be contribute to solve it \\
\hline & Level of intimacy with family and friends and state organizations \\
\hline \multirow[t]{2}{*}{ Social opposition } & $\begin{array}{l}\text { In my opinion, non-local officials work better in Meymand and if there is a conflict between my } \\
\text { relatives with stranger, I will advocate my relatives. }\end{array}$ \\
\hline & Level of conflict with family, friends, and municipality \\
\hline $\begin{array}{l}\text { Network of social } \\
\text { relations }\end{array}$ & $\begin{array}{l}\text { level of communication with family, close relatives, friend and cultural and entertainment centers } \\
\text { and Islamic council }\end{array}$ \\
\hline \multirow{2}{*}{$\begin{array}{l}\text { Belief to necessity } \\
\text { social relations }\end{array}$} & help to neighbors is one of religious necessity \\
\hline & Making decision the affairs relating to our city is the primary task of all people. \\
\hline Social contribution & $\begin{array}{l}\text { contribution with occupational councils, charity councils, local council, participating to making } \\
\text { community }\end{array}$ \\
\hline
\end{tabular}

\section{Research findings}

Table 2 summarizes the mean and the standard deviation of the respondents.

Table 2

Statistical indexes, comparison of average items of social capital and their subgroups

\begin{tabular}{llc}
\hline Components of social capital & Mean & Standard deviation \\
\hline Social trust & 2.751 & 0.530 \\
Interior group trust & 3.498 & 0.843 \\
Exterior group trust & 2.800 & 0.721 \\
Trust to organizations & 2.448 & 0.931 \\
Network of social relation & 3.317 & 0.638 \\
Interior group & 2.59 & 0.661 \\
Exterior group & 3.5 & 0.839 \\
Social solidarity & 3.118 & 0.487 \\
Interior group solidarity & 3.737 & 0.861 \\
Exterior group solidarity & 3.030 & 0.821 \\
Solidarity to organizations & 2.169 & 1.192 \\
Social opposition & 2.399 & 0.508 \\
Interior group opposition & 1.717 & 0.763 \\
Exterior group opposition & 1.997 & 0.855 \\
Opposition to organizations & 2.516 & 1.23 \\
Belief to necessity of social contribution & 3.825 & 0.637 \\
\hline
\end{tabular}

In Table 2, the average dimensions of social capital and subgroups are compared and results show that interior group, exterior group and trust to organizations have received higher score, respectively. In comparison of different dimensions of network of social relation, the exterior group obtains higher than the interior one. In terms of different dimensions of social solidarity, exterior group and solidarity with organizations obtain the highest score, respectively. Our research indicate that the dimensions of social opposition, opposition with organizations, interior group obtain the highest score and finally most of the people believe to the necessity of social contribution. We have used Pearson analysis to study the relationship between social capital and social contribution and the results are summarized in Table 3.

\section{Table 3}

Relationship between social trust and social contribution

\begin{tabular}{lcc}
\hline Variable & Meaningfulness level & Correlation level \\
\hline Interior group trust & 0.000 & 0.265 \\
Exterior group trust & 0.000 & 0.275 \\
Belief to state organizations & 0.000 & 0.217 \\
Social trust & 0.000 & 0.285 \\
\hline
\end{tabular}


Table 4 summarizes the relationships between social opposition and social contribution. As we can observe from the Table, there is a positive and meaningful relationship between social trust and social contribution. (In the level 99\%).

\section{Table 4}

The relationship between social opposition and social contribution

\begin{tabular}{lcc}
\hline \multicolumn{1}{c}{ Variable } & Meaningfulness level & Correlation level \\
\hline Interior group opposition & 0.408 & -0.048 \\
Exterior group opposition & 0.110 & -0.063 \\
Opposition with state organizations & 0.002 & -0.182 \\
Social opposition & 0.013 & -0.145 \\
\hline
\end{tabular}

There is a negative and meaningful relationship between social opposition with organization.

\section{Table 5}

Relationship between the level of propagation of social network and social contribution

\begin{tabular}{lcc}
\hline \multicolumn{1}{c}{ Variable } & Meaningfulness level & Correlation level \\
\hline Network of Interior group relations & 0.088 & -0.099 \\
Network of exterior group relations & 0.000 & -0.318 \\
Network Social relations & 0.000 & -0.283 \\
\hline
\end{tabular}

Again, as we can observe from Table 5, there is a negative and meaningful relationship between network of social relationship of exterior group and social contribution.

Table 6

Relationship between social contribution and social solidarity

\begin{tabular}{lcc}
\hline Variable & Meaningfulness level & Correlation level \\
\hline Interior group solidarity & 0.000 & 0.227 \\
exterior group solidarity & 0.000 & 0.313 \\
solidarity to state organizations & 0.000 & 0.28 \\
Social solidarity & 0.000 & 0.413 \\
\hline
\end{tabular}

Table 6 summarizes the relationship between social contribution and solidarity. It is obvious that there is strong positive relationship between these two factors when the confidence level is 99\%. We have also examined the relationship between social contribution and social contribution and found that the ratio of correlation was 0.255 between these two variables with the p-value of 0.000 . According to correlation coefficient, we obtain regression, equation between contribution and other dimensions of social capital, by applying stepwise; in fourth step we take optimal equation including dimensions of social solidarity, network of social relation and belief to social necessity. By considering the values of standard coefficients, we find that the highest share is associated with solidarity. It means that, for instance, an increase of one unit in solidarity could increase social contribution value by 0.423 .

\section{Table 8}

The summary of the results of stepwise regression model

\begin{tabular}{lllllll}
\hline Name of variable & $\mathrm{B}$ & $\beta$ & $R^{2}$ & P-value & t-value & Correlation \\
\hline Social solidarity & 0.439 & 0.423 & 0.032 & 0.423 & 7.806 & 0.179 \\
Network of social relations & -0.113 & -0.141 & 0.036 & 0.117 & -2.736 & 0.190 \\
Belief to necessity of social relations & 139 & 174 & 0.045 & 0.003 & 2.998 & 0.231 \\
gender & 0.147 & 0.142 & 00.015 & 0.011 & 2.552 & 0.228 \\
\hline
\end{tabular}

According to the effect of social contribution on the trend of social develop in the society, it is necessary to make suitable condition ad beds of leading people to involve in social organizations and volunteering non state councils. Programmers of society should remove legal structural barriers using different ways by developing organizations and necessary sufficient supports to gather people in 
organizations. It is also a good idea to create motivation for people to get memberships in such organizations. These efforts could contribute for developing social capital and increase the level of social trust. The other suggestion in this field is that officials possibly act to promises to improve level of social trust. High social trust shows useful results for the society. In other word, people's motivation will increase to contribute in organizations and voluntary council. In addition, political events will also increasing. Besides, developing and stabilizing social relationships, links and network will be developed and they will play effective roles in social capital. One of suggestive consequence for increasing the level of social trust is to ask the government to decrease social inequalities since this could eliminate many social conflicts. Note that when there is not equal opportunities, we may expect an increase on social crimes such as cheating, abusing the regulations, etc., which make inevitable damages to social trust.

\section{Conclusion}

In this paper, we have presented an empirical study to learn about the relationship between social capital and social contribution. The study of this paper has attempted to find any positive impact of social capital on social contrition. In our survey, we have selected a sample of 300 people out of 5026 people who lived in a small town located in Iran. The survey found positive relationship between social trust and social contribution and between social contribution and social solidarity, while there was a negative relationship between social opposition and social contribution and between the level of propagation of social network and social contribution. We have also performed a stepwise linear regression method between social contribution and other dimensions of social capital and discussed the results in details.

\section{References}

Cahill, M. (2005). Is the human development index redundant?. Eastern Economic Journal, 31(1), 1-5.

Chaplin, W. F. (1997). Personality, interactive, relations, and applied psychology. In R. Hogan, J. Johnson, \& Briggs, S. (Eds.), Handbook of personality psychology, 873-890, San Diego, CA: Academic Press.

Cobb, C.W., \& Cobb, J.B. (1994). The Green National Product: A Proposed Index of Sustainable Economic Welfare, University Press of America, Lanham, MD.

Cronbach, L. J. (1951). Coefficient alpha and the internal structure of tests. Psychometrika, 16(3), 297-334.

Dijkstra, G.A., \& Hanmer, L. (2000). Measuring socio-economic gender inequality: towards an alternative to the UNDP gender-related development index. Feminist Economics, 6(2) 41-75.

Likert, R. (1932). A Technique for the Measurement of Attitudes. Archives of Psychology, 140, 1-55.

McGillivray, M., \& White, H. (1993). Measuring development? The UNDP's human development index. Journal of International Development, 5(2), 183-92.

Nascimento, D.M., \& Marteleto, R.M. (2008). Social field, domains of knowledge and informational practice. Journal of Documentation, 64(3), 397-412.

Natoli, R., \& Zuhair, S. (2010). What is a reasonable measure of progress?. International Journal of Sociology and Social Policy, 30(5-6), 201-218.

Orhan, M., \& Scott, D. (2001). Why women enter into entrepreneurship: an explorative model. Women in Management Review, 16(5), 232-47.

Park, S., \& Bae, Z.T. (2004). New venture strategies in a developing country: identifying a typology and examining growth patterns through case studies. Journal of Business Venturing, 19(1), 81-105.

Roomi, M. A., Harrison, P., \& Beaumont-Kerridge, J. (2009). Women-owned small and medium enterprises in England: Analysis of factors influencing the growth process. Journal of Small Business and Enterprise Development, 16(2), 270-288.

Reamer, F. G. (2006). Ethical Standards in Social Work: A Review of the NASW Code of Ethics. ${ }^{\text {nd }}$ ed., Washington, DC: NASW Press. ISBN 9780871013712.

United Nations Development Programme (UNDP) (1990). Human Development Report 1990: Concept and Measurement of Human Development, Oxford University Press, New York, NY.

Werbel, J.D., \& DeMarie,S. M. (2005). Aligning strategic human resource management and personenvironment fit. Human Resource Management Review, 15(4), 247-262.

William, S.J. \& White, E.B. (1999). The Elements of Style, $4^{\text {th }}$ ed., Boston: Allyn \& Bacon, ISBN 9780205313426. 